\title{
Improving Industrial Engineering Performance through a Successful Project Management Office
}

\author{
Seweryn Spalek \\ Silesian University of Technology \\ Akademicka $2^{a}$; 44-100 Gliwice; Poland \\ e-mail: spalek@polsl.pl
}

cross ${ }^{\text {ref }}$ http://dx.doi.org/10.5755/j01.ee.24.2.3087

\begin{abstract}
The improvement of industrial engineering performance is currently a key issue. Companies can achieve such an improvement in different ways. One way, especially for companies operating in a multi-project environment, is a successfully operating Project Management Office (PMO). Recent studies have revealed that a successful PMO is a key factor influencing organisational performance. The author of this study conducted a world-wide research with a sample of over four hundred PMO cases to identify what determines the success of their operations. This study revealed that to achieve a successfully operating PMO, we should focus on the activities of the PMO during two periods: short term (up to one year) and long term (two or more years). Consequently, in each of these time frames, there are different issues that need to be addressed to run a successful PMO and, thus, improve industrial engineering performance. Moreover, the efficacy of operations in a multi-project environment is crucial for practitioners. Therefore, the findings of this research will help managers to improve organisational performance, which should result in the ability to manage more projects on time and within the budget and scope of the PMO. This paper advances the current state of knowledge on PMO success factors and explores new research areas.
\end{abstract}

Keywords: Organisational Performance, Success, Project Management, Project Management Office, PMO, Challenges, Start-up, Empirical Research, Operational Management, Industrial Engineering.

\section{Introduction}

The general influence of project management on organisational performance has been the subject of several studies and the outcomes of these studies are ambiguous. However, Anumba et al., (2002) noted that proper organisational structures lead to better efficacy in the management of projects and therefore improve the outcomes in the construction industry. In their recent work, Aubry and Hobbs (2011) concluded that "Research on organisational performance in project management does not produce entirely satisfactory results. Each piece of the research brings important contributions - but considered altogether, a global vision of project management performance at the organisational level is still lacking". However, in their opinion we should search for ways to improve organisational performance through different components and entities. Therefore, they conducted research and recognised the Project Management Office (PMO) as a key factor influencing organisational performance.

We agree with this approach and, building on it, we argue that through a successfully operating PMO, we can improve the organisational performance of the company in different areas of its activities. One of them is industrial engineering.

Furthermore, Georgy et al., (2005) have pointed out that there is a critical link between industrial engineering performance and efficient management of the project's life cycles, especially in the multi- project environment. Therefore, we argue that in order to improve the efficacy of managing several projects in an industrial company, there is a need to run successfully operating PMO.

However, despite research on PMOs, there is still a knowledge gap and a lack of common understanding on what drives their success. Therefore, it is crucial to learn more about the nature of PMOs, the key factors influencing their successful operations and the challenges they face. Knowing them and applying them in practice would definitely help managers to attain the expected outcomes from the projects run by their companies and improve organisational performance.

Note that PMO could be a facilitator of human resources and its implications for projects, the importance of which was highlighted by Standing et al., (2006) and Liang et al., (2007), by providing an informative and integrated approach, as described by Czuchry (2003), supporting ERP (Huang et al., 2004; Okrent \& Vokurka, 2004) and ES implementations (Soja \& Paliwoda-Pekosz, 2009), managing risks in projects (Dey et al., 2007; Faisal et al., 2007; Huang et al., 2004) and integrating projects, as described by Gulledge (2006).

The Project Management Office (PMO) concept was proposed in the 1990s (Kerzner, 2003), and in the beginning, it appeared similar to other departments in the organisation (e.g., Human Resources or IT). Rad and Levin (2002) stated that one of the primary functions of PMO is to support and manage projects. PMO also plays an important role in IT rollout projects (Maguire et al., 2010).

PMO as a research topic has been recognised recently by several authors from different functional areas, including 
(Andersen et al., 2007; Arbaugh, 2007; Aubry et al., 2011; Blunden, 2010; Bucur \& Onete, 2008; Cano et al., 2008; Curlee, 2008; Desouza \& Evaristo, 2006; Engle, 2005; Henard \& Szymanski, 2001; Hill, 2004; Hoang \& Rothaermel, 2005; Lewis et al., 2002; Isola et al., 2006; Julian, 2008; Kropf \& Scalzi, 2008; Levina \& Su, 2008; Liu \& Yetton, 2007; Lopez-Paredes et al., 2010; Martin et al., 2007; Meredith \& Mantel, 2011; Pellegrinelli, 2011; Singh et al., 2009; Spalek, 2010; Umble, 2003).

Furthermore, international communities have also recognised PMO in their standards (Project Management Institute - PMI, 2008; International Project Management Association - IPMA, 2006). PMI (2013) defines the roles of PMO as follows: "A primary function of PMO is to support project managers in a variety of ways which may include, but are not limited to: (1) Managing shared resources across all projects administered by PMO, (2) Identifying and developing project management methodology, best practices, and standards (3) Coaching, mentoring, training, and oversight (4) Monitoring compliance with project management standards, policies, procedures, and templates by means of project audits (5) Developing and managing project policies, procedures, templates, and other shared documentation (organizational process assets), and (6) Coordinating communication across projects". While IPMA (2006) states: "A project management office (or programme management or portfolio management office) is part of a permanent organization. Its roles are typically to support, to set standards and guidelines for the managers of different projects and programmes, to collect project management data from the projects, to consolidate it and to report to some governing body. It has to ensure that the projects are aligned to the organisation's strategy and vision".

Moreover, we can distinguish its main supporting roles in the following areas of the companies activities: human resources (Bratnicki, 2005; Zavadskas, 2012), methods and tools (Beringer et al., 2012; Trocki et al., 2012), environment (Ritter and Gemunden, 2004; Romanowska, 2009; Spalek, 2012; Stabryła \& Wozniak, 2012) and knowledge management (Gasik, 2011; Liebowitz, 2003; Lindner \& Wald, 2011; Paliszkiewicz, 2007; Pemsel \& Wiewiora, 2013; Piraquive et al., 2013)

Considering the abovementioned definitions and articles written on the topic of PMOs, we can assume that PMOs vary significantly, which was highlighted in the paper by (Hobbs \& Aubry, 2006a; Aubry et al., 2011). The abovementioned authors show how comprehensive PMOs can be, the numerous challenges that could be associated with running PMO and how important it is to conduct more empirical research.

Therefore, to reduce the knowledge gap regarding PMOs, we would like to contribute to the current state of knowledge by formulating a general research question:

RQ: What drives the success of a PMO?

Our considerations are based on the research and the results of a world-wide study of more than 400 PMOs.

\section{Empirical research on PMOs in the literature}

To obtain an understanding of PMOs, empiricallygrounded studies were conducted by researchers. The results of the most significant studies started to be published in highly recognised international journals at the beginning of the present century. Among these studies, Dai and Wells (2004) noticed that the reasons for establishing PMOs could vary significantly. Desouza and Evaristo (2006) investigated the critical success factors (CSFs) and the roles of PMOs. They identified six CSFs and three types of PMO roles. A study of information system projects was conducted by Martin et al., (2007) based on interviews with 129 project managers. They summarised their discussions about the presence of PMOs in organisation and project management practices. Suggestions for setting up PMOs and recommendations for their efficient functioning were provided by Hatfield (2008). The notable research of Hobbs and Aubry (2008) was based on the extensive research of 500 snapshots of PMOs, and they identified three types of PMOs. Furthermore, they underlined the significant variability among PMOs. Moreover, remarkable studies were conducted by Hobbs et al., (2008), who showed that PMOs have very unstable structures and that the majority of PMOs are transformed every 3-4 years. In addition, the knowledge base was expanded by the research of Hurt and Thomas (2009) who conducted three PMO case studies indepth, showing that within several years, all PMOs reported success stories. Only one of these PMOs started to struggle, but only after nine years of operations. As PMOs tend to be unstable and are affected by the company's organisational changes, an interesting study of the forces and factors of PMO changes was conducted by Aubry et al., (2010a). The short life span (very often not exceeding a two-year period) of PMOs was noted in the research of (Hobbs \& Aubry, 2007; Interthink, 2002; Stanleigh, 2006). Aubry et al., (2010a) concluded that it is difficult to identify the set of PMO set-up characteristics that should influence the survival rate of PMO in the long term. We agree with the conclusion that there are no initial factors influencing this survival rate in the long term.

However, we assume that there are certain PMO startup factors that influence the survival rate in the short term, and this aspect will be investigated in this paper based on empirical research on more than 400 cases. In addition, we will focus on the challenges that PMOs face during their operations in the long term.

Therefore, we identified two knowledge gaps we would like to cover:

(1) What are the challenges of PMO start-up (for short-term success considerations)?

(2) What are the challenges during PMO operations (for long-term success considerations)?

We believe that by better understanding various timedependent challenges, we will be able to effectively shape PMOs to improve organisational performance.

Based on the above-stated discussions, two specific research questions emerged:

RQ1 - Are there start-up factors influencing the survival rate of PMO in the short term (i.e., up to one year)?

RQ2 - Can we determine the challenges PMO might face in the long term (i.e., more than one year from its startup)? 


\section{Methodology}

Based on the literature review, we argue that improvement in organisational efficacy influences industrial engineering performance. Moreover, the results of the empirically-grounded research conducted by some authors revealed that Project Management Offices have a positive impact on organisational performance. Therefore, the need arose to carry out some research on the issues related to PMO's success.

\section{Data collection and sample}

To better understand the challenges PMO encounters, we decided to focus on two aspects: (1) issues during the start-up of PMO with a short-term life span (short-term challenges) and (2) challenges that appear during the operational phase in the long-term (long-term challenges), which could result in the shutting down of PMO. To identify short- and long- term challenges, a research study was conducted, based on the descriptive survey of PMO case studies. To collect the data, a web questionnaire was compiled and published on the Project Management Institute website. Furthermore, the members of the Forum of PMI Program Management Office Specific Interest Group were invited to participate in the survey. As a result of that world-wide survey, 444 case studies of PMOs were collected from a wide variety of industries.

\section{Questionnaire}

The questionnaire was divided into three key parts to support major research areas (RA) for short-term considerations:

- $\quad$ RA \#1 - to collect data related to PMO start-up process and identify the relationship of selected activities to the survival rate of PMOs.

and for long-term considerations:

- $R A \# 2$ - to ascertain the reasons for shutting down PMOs.

- $\quad$ RA \#3 - to identify the main challenges PMOs are confronted with if they are still in operation.

Research Area \#1

In the first area, questions on scope definition, success criteria definition and top management support at the startup of PMO were asked to advance the current state of knowledge (Hobbs and Aubry, 2007; Interthink, 2002; Stanleigh, 2006). Moreover, to expand the knowledge of PMOs, issues related to PMO initiators were investigated.

Research Area \#2

In the second area, the reasons for shutting down PMOs were analysed. Among them, the most significant were (1) not demonstrating added value, (2) top management reluctance, (3) staff resistance, (4) inability to demonstrate added value and (5) the lack of scope of activities and as well as high operation costs.

Research Area \#3

In the third area, continuously active PMOs were investigated in terms of their challenges.

The selected set of occurrences investigated in the chosen areas is shown in table 1.

Building on previously conducted studies by other authors (Hobbs \& Aubry, 2007; Interthink, 2002; Stanleigh, 2006) and with the goal of advancing our knowledge regarding $\mathrm{PMO}$ shutdowns, we decided to make the following assumptions on the surveyed periods of PMO operations:

- $\quad$ short term; up to 1 year,

- $\quad$ long term; subgrouped (where applicable) into 2-4 years, 5-10 years and over 10 years.

Table 1

The set of selected investigated occurrences

\begin{tabular}{|c|c|}
\hline Research Area & Selected investigated occurrences \\
\hline \multirow[t]{4}{*}{ \#1 } & Top management support \\
\hline & Definition of PMO success criteria \\
\hline & Definition of scope of activities \\
\hline & Groups of PMO start-up initiators \\
\hline \multirow[t]{5}{*}{$\# 2$ and $\# 3$} & $\begin{array}{l}\text { Inability of PMOs to demonstrate } \\
\text { added value }\end{array}$ \\
\hline & Top management reluctance \\
\hline & Staff resistance \\
\hline & Lack of scope definition \\
\hline & Unacceptable operating costs \\
\hline
\end{tabular}

The study is mostly descriptive. However, where applicable and to measure the relationship between variables, chi-square statistics were used and crosstabs were analysed. The research instrument was validated with a Cronbach's Alpha test.

\section{Results and Discussion}

Out of the total sample of 444 cases, we found that in thirty cases, PMOs were created on a temporary basis to serve a specific need for a limited period of time. In our research, we focused on PMOs that were established with the intention of becoming a permanent body in the organisational structure. Therefore, for the purposes of this study, we consider 414 cases of PMOs.

Companies using PMOs and operating in the following five geographical regions (more than one region of operation could be chosen in the questionnaire) were included: (1) Asia and Pacific - AP, (2) Europe - EUR, (3) Middle East and Africa - MEA, (4) North America - NA and (5) South and Latin America - SLA. No significant correlation was observed between the operational region and the PMO shutdown rate, an observation that was also made in the study of Hobbs and Aubry (2008). Some regional differences were noticed in the SLA and MEA. However, we believe that these differences were due to an insubstantial sample of data and cannot be generalised as a conclusion. The two biggest samples representing North America and Europe yielded nearly the same results.

A total of $12.3 \%(\mathrm{~N}=51)$ of all considered PMOs were shut down, $23.4 \%$ of which shut down within a year; 47.6 $\%$ within 2-4 years; $27.2 \%$ within 5-10 years and only 1.8 $\%$ shut down more than 10 years after their start-up. It is significant that $88 \%$ of those PMOs were shut down before they matured to 5 years.

Our results agree with those of Aubry et al., (2010b), suggesting that it is most likely difficult to identify PMO start-up factors that influence the failure of PMOs in the long term (more than one year after start-up). In fact, in our research we did not find any correlations between PMO start-up factors and long-term survival rate. However, we discovered certain start-up variables that could determine the survival of PMO in the short term (up 
to one year). Therefore, we decided to determine whether there are any elements influencing the short-term survival rate of specific PMOs.

\section{Short-term considerations}

Our intention was to inquire whether start-up occurrences such as the definition of the measurable criteria of PMO success, the definition of PMO scope of activities and the top-management support were related to PMO's survival rate in the short term. Therefore, the answers to the following questions were analysed:

- Were the measurable criteria of PMO success defined before PMO start-up?

- Was the scope of PMO activities clearly defined before the start-up?

- Did PMO have top management support at its start-up?

The numbers of PMOs meeting the above-stated criteria are shown in table 2.

Number of PMOs meeting the chosen criteria

Table 2

\begin{tabular}{|l|c|c|c|}
\hline \multirow{2}{*}{} & $\begin{array}{l}\text { Were the } \\
\text { measurable } \\
\text { criteria of PMO } \\
\text { success defined } \\
\text { before PMO } \\
\text { start-up? }\end{array}$ & $\begin{array}{l}\text { Was the scope } \\
\text { of activities of } \\
\text { PMO clearly } \\
\text { defined before } \\
\text { the start-up? }\end{array}$ & $\begin{array}{l}\text { Did PMO } \\
\text { have top- } \\
\text { management } \\
\text { support at its } \\
\text { start-up? }\end{array}$ \\
\hline \multirow{2}{*}{ Yes } & 158 & 241 & 336 \\
\hline $\begin{array}{l}\text { No } \\
\text { Don't } \\
\text { Know }\end{array}$ & $38 \%$ & $58 \%$ & $81 \%$ \\
\hline \multirow{2}{*}{ TOTAL } & 256 & 173 & 78 \\
\cline { 2 - 4 } & $62 \%$ & $42 \%$ & $19 \%$ \\
\hline
\end{tabular}

To further our analysis, we decided to consider the data for which at least one of the three start-up occurrences was present $(\mathrm{N}=330)$. Of these data, only top management support showed a significant relationship to the short-term survival rate and only during the period of up to one year $(p=0.003)$.

If there was top management support $(\mathrm{N}=289)$, only $6.5 \%(\mathrm{~N}=19)$ of PMOs were closed and only $2.4 \%(\mathrm{~N}=7)$ in the first year, out of a total number of forty five (13.6\%) of all closed PMOs and 5.8\% $(\mathrm{N}=19)$ in the first year.

We also considered combinations of the selected criteria and their outcome.

If all three criteria were met $(\mathrm{N}=121)$, the number of PMO shutdowns in the first year decreased to four $(3.3 \%)$. Note that three PMOs were closed because the operating costs were not acceptable. Moreover, if the measurable criteria of PMO success was defined before PMO start-up and top management support was present $(\mathrm{N}=142)$, the number of PMO shutdowns in the first year decreased to four $(2.8 \%)$. Furthermore, if the scope of activities of PMO was clearly defined before the start-up and top management support was present $(\mathrm{N}=211)$, the number of PMO shutdowns in the first year dropped to six $(2.8 \%)$. Note that meeting two or more criteria does not improve the short-term survival rate significantly compared to the single appearance of top management support.
Note that if none of the three criteria was met $(\mathrm{N}=20)$, the number of PMO shutdowns was two $(10.0 \%)$, one of which was cancelled within the first year and the other within the 2-4 year period. Despite the insufficient sample size and the inherent shortcomings of our results, we were able to draw the limited conclusion that in the short term, the absence of all three considered factors at the start-up of PMO would negatively influence the survival rate of PMO.

Because top management support has a strong positive influence on PMOs' survival rate in the short term, we sought to determine whether there was any relationship between the initiator and top management support. Therefore, we investigated four groups of initiators:

- One or more of the Top Managers (TOP);

- One or more of the Middle-level Managers (Middle);

- One or more of the Project Managers (PM);

- External, e.g., consultancy company (EXT).

A very strong relationship was observed between one of the top managers as an initiator of PMO and the support of top management $(p<0.001, \mathrm{~N}=268)$ because almost 93 $\%$ of PMOs had the support of top management. For initiators from at least one of the other groups (i.e., Middle level managers, Project Managers and External consultants), the percentage of PMOs supported by top management decreased to $60 \%, 61.5 \%$ and $75 \%$, respectively. The detailed data are shown in table 3 .

Table 3

The number of PMOs with top management support in relation to the chosen initiators

\begin{tabular}{|l|c|c|c|c|}
\hline \multirow{3}{*}{$\begin{array}{c}\text { Top management } \\
\text { support }\end{array}$} & $\begin{array}{c}\text { Initiators } \\
\text { At least } \\
\text { TOP }\end{array}$ & $\begin{array}{c}\text { At least } \\
\text { Middle } \\
\text { (TOP } \\
\text { excluded) }\end{array}$ & $\begin{array}{c}\text { At least } \\
\boldsymbol{P M} \\
\text { (TOP } \\
\text { excluded) }\end{array}$ & $\begin{array}{c}\text { At least } \\
\text { External } \\
\text { (TOP } \\
\text { excluded) }\end{array}$ \\
\hline \multirow{2}{*}{ Yes } & 249 & 42 & 24 & 18 \\
\cline { 2 - 5 } & $92.9 \%$ & $60.0 \%$ & $61.5 \%$ & $75.0 \%$ \\
\hline \multirow{2}{*}{ No } & 11 & 22 & 12 & 3 \\
\cline { 2 - 6 } & $4.1 \%$ & $31.4 \%$ & $30.8 \%$ & $12.5 \%$ \\
\hline \multirow{2}{*}{ Don't know } & 8 & 6 & 3 & 3 \\
\hline \multirow{2}{*}{ TOTAL } & $3.0 \%$ & $8.6 \%$ & $7.7 \%$ & $12.5 \%$ \\
\cline { 2 - 5 } & $\mathbf{2 6 8} \%$ & $\mathbf{7 0}$ & $\mathbf{3 9} \%$ & $\mathbf{2 4}$ \\
\hline
\end{tabular}

Because initiators could come from two or more groups, we also analysed occurrences of pairs of initiators: (1) at least Middle \& PM, with TOP excluded; (2) at least TOP \& Middle; (3) at least TOP \& PM and (4) at least $T O P \& E X T$ (see table 5). Due to the relatively small number of samples, it is difficult to generalise the outcomes. However, note that if the initiators both came from the Top Managers and Project Managers groups, all projects $(100 \%)$ had top management support at their start-up. Furthermore, the TOP \& Middle pair resulted in more than $97 \%$ of PMOs being supported by top management, while the TOP \& EXT pair reported a $92 \%$ support rate. This result suggests that if initiators from Middle or $P M$ come together in pairs with top management, the rate of top management support of PMOs is improved compared to the situation where TOP is the initiator. However, being aware of the size limitations of the sample, additional more comprehensive studies should 
be considered. Moreover, more than $66 \%$ of PMOs were supported by the top management if the initiators Middle Managers and Project Managers collaborated. This result was slightly better compared to PM and Middle as separate initiators.

Table 4

The number of PMOs with top management support in relation to the chosen pairs of initiators

\begin{tabular}{|l|c|c|c|c|}
\hline \multirow{2}{*}{$\begin{array}{c}\text { Top } \\
\text { management } \\
\text { support }\end{array}$} & $\begin{array}{c}\text { At least } \\
\text { Middle\&PM } \\
\text { (TOP } \\
\text { excluded) }\end{array}$ & $\begin{array}{c}\text { Initiators } \\
\text { AOP\&Middle }\end{array}$ & $\begin{array}{c}\text { At least } \\
\text { TOP\&PM }\end{array}$ & $\begin{array}{c}\text { At least } \\
\text { TOP\&EXT }\end{array}$ \\
\hline \multirow{2}{*}{ Yes } & 12 & 38 & 21 & 23 \\
\cline { 2 - 5 } & $66.7 \%$ & $97.4 \%$ & $100.0 \%$ & $92.0 \%$ \\
\hline \multirow{2}{*}{ No } & 5 & 1 & 0 & 0 \\
\hline \multirow{2}{*}{ Don't know } & $27.8 \%$ & $2.6 \%$ & $0.0 \%$ & $0.0 \%$ \\
\cline { 2 - 5 } & 1 & 0 & 0 & 2 \\
\hline \multirow{2}{*}{ TOTAL } & $5.6 \%$ & $0.0 \%$ & $0.0 \%$ & $8.0 \%$ \\
\cline { 2 - 5 } & $\mathbf{1 0 0} \%$ & $\mathbf{1 8} \%$ & $\mathbf{2 1}$ & $\mathbf{2 5}$ \\
\hline
\end{tabular}

\section{Long-term considerations}

As expected, for PMOs operating for more than one year, we observed no significant relationship between the start-up factors and PMO survival rate.

Therefore, we focused on the descriptive data analysis to determine and describe the reasons for shutting down PMOs. We examined the following causes for the dissolution of PMOs:

- $\quad$ PMO was not able to demonstrate added value to the organisation;

- $\quad$ The top managers opposed PMO;

- The staff opposed PMO;

- The lack of definition of PMO's scope of activities;

- $\quad$ The costs of operating PMO were not acceptable.

The respondents were able to indicate more than one reason for the shutdown. Thanks to the survey, we found that 25 PMOs were closed 2 to 4 years after their start-up and 7 were closed after 5-10 years; the reasons for the closures varied significantly (Figure 1).

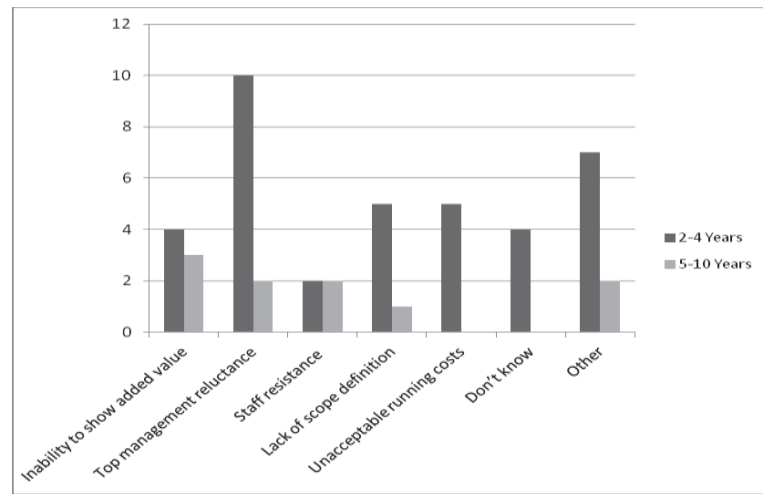

Figure 1. The numbers of shut-down PMOs by periods of time and by cause

However, due to the low number of sampled PMOs for the 5-10 year period, it is not feasible to make generalisations of statistical significance. Furthermore, based on the limitation of the sample, in our further investigations we decided to combine two periods of time and analyse the data for the newly selected time frame of 2-10 years. Using that particular approach, we were able to analyse a sample of 32 cases, which is at least sufficient for a descriptive analysis of these cases.

The reasons for shutting down PMOs in the considered 2-10 year time period are shown in figure 2. The main direct reason $(37.5 \%)$ for shutting down PMO was the fact that top management was against PMO. However, note that in 6 cases (out of 12), top management was given as a single reason for shutting down PMO. In 6 cases, this reason was combined with at least one other reason.

The second most stated factor $(28,1 \%)$ was company reorganisation. However, we could classify most of these reorganisations as being due to different variables, e.g., economic downturn, new vision of the company, or refocusing of activities. Furthermore, the survey results indicated that the reasons (1) PMO was not able to demonstrate added value to the organisation, (2) The lack of definition of PMO's scope of activities, (3) The costs of operating PMO were not acceptable were reported in 21.9 $\%, 18.8 \%$ and $15.6 \%$ of cases, respectively. In our opinion, the first reason should especially be noted by people interested in PMO success. This reason shows that we should search for different methods that allow PMOs to demonstrate added value to organisations, supporting the long-term survival rate of PMO. Staff resistance and the answer 'don't know' received the same level of responses $(12.5 \%)$, which is not considered significant.

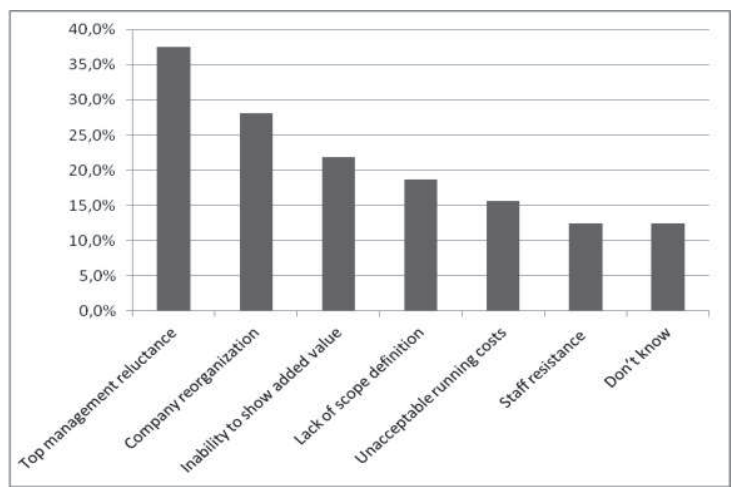

Figure 2. The reasons for shutting down PMOs within a 210 years

The third area of investigation considered the challenges that PMOs met while operating. The number of surveyed PMOs still in operation was 338, and most of these surviving PMOs were 2-4 years old $(\mathrm{N}=161) ; 92$ were 5-10 years old and 79 were younger than one year. Moreover, only 6 PMOs were older than 10 years.

Interesting results were obtained by observing the challenges that PMOs faced due to their age (Figure 3). Note that the challenges of inability to demonstrate any added value, reluctance of top management, staff resistance and unacceptable PMO operating costs were nearly at the same level in all age groups, with values of approximately $30 \%, 12 \%, 24 \%$ and $12 \%$, respectively. However, the lack of defined scope of activities decreased from nearly $50 \%$ to just over $20 \%$ across the age groups. In our opinion, this result means that after years of 
operating, PMOs matured away from their initial scope of activities towards focusing on fulfilling the needs of the company. Furthermore, the group of other factors increased from nearly $20 \%$ to $35 \%$. However, the analysis of open answers showed a large variety of challenges that could not be classified into any predefined subgroup, supporting to some extent the hypothesis that PMOs face a continuum of changes due to the dynamics of their organisations (Aubry et al., 2010).

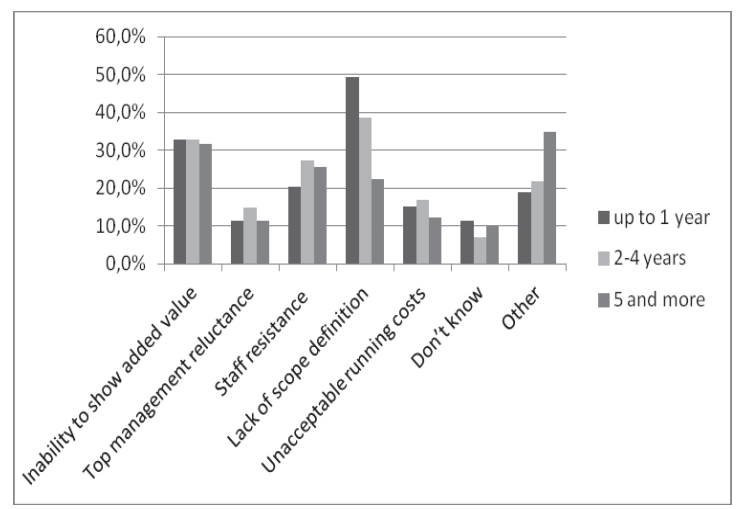

Figure 3. The challenges of surveyed and still operating PMOs by age groups

If we consider all PMOs that were still operating (Figure 4) after two or more years $(\mathrm{N}=259)$, the most common challenges $(32.4 \%)$ are inability to demonstrate added value and lack of scope definition. However, the second factor showed a tendency to decrease over the years of operation. Demonstrating added value, in our opinion, is vital for PMO operations. Moreover, the difficulty is how to measure and report added value, a point clearly outlined by Aubry \& Hobbs (2011); Hobbs \& Aubry (2008); Liu \& Yetton (2007); and Martin et al., (2007), and we believe that further studies are needed to advance the current state of knowledge. The next two factors at 26.6 $\%$, are staff resistance and other. Regarding other in the open question, the respondents indicated a wide variety of challenges, which are difficult to group under a common label. However, a number of these challenges increased over the years of operation, and we can observe frequently stated answers that can be grouped under the label "reorganisation of the company". Note that unacceptable operating costs and reluctance of top management received relatively low scores of $13.5 \%$ and $8.1 \%$.

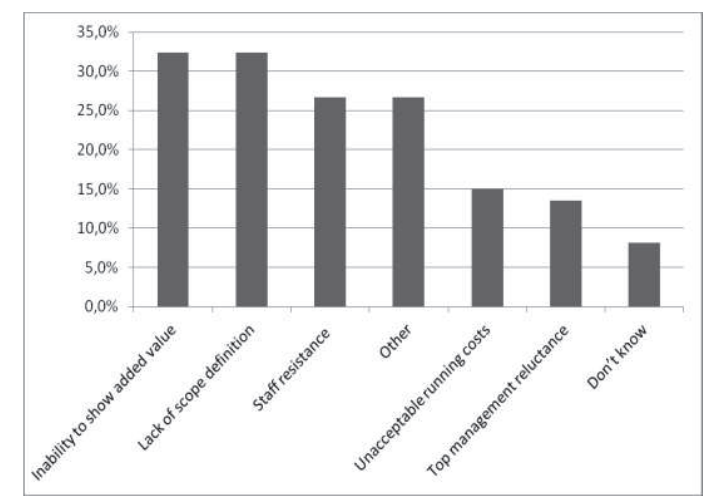

Figure 4. The challenges of PMOs operating for two or more years

\section{Industrial engineering implications}

Industrial engineers currently are eager to find ways to improve operational performance, which should lead to an increase in the number of projects completed on time and within the desired budget and scope. In recent years, due to the economic downturn, only the most efficient organisations can survive. Companies running an increasing number of projects simultaneously need to know what types of measures they should take to increase the efficacy of their operations in a multi-project environment; therefore, PMOs tend to play a key role. However, practical applications reveal a huge knowledge gap regarding how to successfully establish and operate PMO. Based on the findings of our research, we can advise managers to focus on two different timeframes while establishing and running PMO:

(1) short term; up to one year from PMO start-up;

(2) long term; two and more years from PMO start-up.

In the short term, it is crucial for practitioners to perform certain activities before PMO set-up. Those activities should include the creation of a group of initiators or idea supporters, consisting of a combination of top and middle managers (including project managers). Such a group ensures adequate support of operations within PMO's first crucial year. During the set-up process, it is advisable to define the success criteria and the scope of activities. The latter will also provide a good basis for the long-term success of operations.

In the long term, managers should be aware that PMO has to evolve together with the company in its turbulent environment. Furthermore, PMO should be able to demonstrate the added value it creates to the company and provide an adequate definition of its scope of work. Moreover, staff resistance is an issue that should be managed in advance. Focusing on a reduction of PMO's operational costs is a must.

Taking care of short- and long-term issues will result in a successfully operating PMO, leading to enhanced efficacy in the management of operations in the company and improving its organisational performance.

\section{Conclusions}

Based on our studies, we can assume that PMOs faced with a significant variety of challenges, consistent with the observations of Hobbs and Aubry (2008). We agree that due to an ever-changing environment, PMOs are forced to constantly adapt (Aubry et al., 2010a; Hobbs et al., 2008; Hurt \& Thomas, 2009).

Furthermore, we conclude that it is hard to determine the specific PMO start-up configuration that should influence the survival rate of PMOs in the long term (more than one year from PMO initiation).

However, we found that in a short period of time (up to one year from PMO start-up), there are start-up factors that can increase the survival rate of PMOs.

In our studies, we focused on the short- and long-term issues separately. As a result, we analysed data of PMO cases in three research areas $(R A)$, one in the short term and two in the long term: 
(1) RA \#1 - PMOs that were shut down within the first year of their operations.

(2) RA \#2 - PMOs that were shut down more than one year after their inception.

(3) RA \#3 - PMOs that were operational for 2 or more years and that were still operating.

In the first area, we concluded that there is a very significant relationship between top management support and the survival rate of PMOs. Only $2.4 \%$ of PMOs that have top management support were closed within the first year, in sharp contrast to the total of PMOs that were shut down over the same time period $(5.8 \%)$. This reduced the number of failed PMOs by more than half. Contrary to our expectations, we did not discover a significant influence of the other two factors scope of activities definition and success criteria definition, on the survival rate within the first year. However, we would recommend further in-depth studies in this area because there may be some dependencies related to the specific types of PMOs. Furthermore, assuming that top management support is crucial, we investigated the relationship between the groups of PMO initiators and management support. We found a strong relationship between one of the top managers as the initiator and the support of top management for PMOs at start-up. A total of $92.9 \%$ of PMOs initiated by one of the top managers had top management support. Moreover, we discovered that if PMO initiation is activated by one of the top managers and project managers, all PMOs (100 \%) received top management support at the start-up. The combinations of top \& middle managers and top \& external consultancy initiators resulted in $97.4 \%$ and $92 \%$ levels of support, respectively. Note that if the initiation came from middle managers, project managers, external consultancy firms and combinations of these positions (without any involvement of top management), then the support of top management ranged between $60 \%-75 \%$. Therefore, we can conclude that PMOs receive the strongest levels of support at their start-up from top management if one of the top managers is involved as an initiator (alone or, preferably, together with one of the project managers, middle managers or external consultancy).

The second and third research areas focused on the challenges that could occur in all long-term operations of PMOs, with a separate focus on the shut down and still operating PMOs.

In the second area, after analysing the results, we focused on 32 cases of PMOs that were closed after two or more years of operations. We discovered the following top three challenges leading to the shutdown of PMOs: the lack of top management support, wide variety of companies' transformation/changes and inability to demonstrate added value. In particular, the ability to demonstrate added value appears crucial for the survival of $\mathrm{PMO}$, and the question of how to demonstrate the added value of PMOs remains open for further studies. Those results provide a fresh view on the topic of companies' transformation/changes and advance findings from other studies on the relationship between the companies' environment and PMOs' operations (Aubry et al., 2010b; Hobbs et al., 2008; Hurt \& Thomas, 2009). However, being aware of the research limitations connected with the limited number of sampled cases, we could draw only limited conclusions to better understand the nature of the challenges PMOs are currently facing. Nevertheless, further study in that area using a larger sample is advised.

The third area represented by the 259 cases of PMOs remaining in operation for two or more years revealed interesting results. We determined that:

- $\quad$ inability to demonstrate added value;

- $\quad$ and the lack of a scope definition.

were the main challenges reported in more than $30 \%$ of the surveyed PMO cases. The first result (reporting a similar value across the years of PMO operations) shows the importance of identifying ways of measuring and reporting added value. Despite previous attempts, as described in the works of (Aubry \& Hobbs, 2011; Liu \& Yetton, 2007), there is a lack of more comprehensive studies in that field, and more research is thus needed in the area of demonstrating added value of PMO. Concerning the lack of an adequate definition of scope, we noticed that this challenge decreased over the time of PMO operation from nearly $50 \%$ to just above $20 \%$. In our opinion, this tendency shows that PMOs mature over their years of operation, and, as a result of reaching more maturity, they are able to improve the definitions of their scope of activities. Two factors with an incidence rate of more than $25 \%$ were (1) staff resistance and (2) the factor reported as 'other', in which we identified the vast majority of challenges. However, we can summarise some of these challenges as internal companies' transformations/changes, supporting the thesis proposed by Aubry et al., (2010) that PMOs are being driven to change by the companies. Note that this factor increased from nearly $20 \%$ to $35 \%$ over the time of operations of the surveyed PMOs, showing that it is the largest challenge of PMOs operating for 5 or more years.

Based on the empirical research conducted, we conclude that the challenges PMOs face are different in the short term (up to one year) and long term (above one year). Moreover, some of the long-term challenges evolve over time, whereas others remain at the same level. We believe the results of our survey help to better understand the complicated nature of PMOs, add new elements to the current understanding of PMOs and originate new research areas in the field of operational management. Applying that knowledge to existing practices should lead to the improvement in industrial engineering performance through the increase of the efficacy in simultaneously managing several projects in the company. Moreover, the efficiency of operations in the multi-project environment can be enhanced by establishing and running PMO. Therefore, we argue that successfully operating Project Management Office positively influences industrial engineering performance in the company. 


\section{References}

Andersen, B., Henriksen, B., \& Aarseth, W. (2007). Benchmarking of Project Management Office Establishment: Extracting Best Practices. Journal of Management in Engineering, 23(2), 97-104. http://dx.doi.org/ 10.1061/ (ASCE)0742-597X(2007)23:2(97)

Anumba, C. J., Baugh, C., \& Khalfan, M. M. A. (2002). Organisational Structures to Support Concurrent Engineering in Construction. Industrial Management \& Data Systems, 102(5-6), 260-270. http://dx.doi.org/10.1108/ 02635570210428294

Arbaugh, J. B. (2007). Introduction: Project Management Education: Emerging Tools, Techniques, and Topics. Academy of Management Learning \& Education, 6(4), 568-569. http://dx.doi.org/10.5465/AMLE.2007.27694956

Aubry, M., Richer, M. C., Lavoie-Tremblay, M., \& Cyr, G. (2011). Pluralism in PMO Performance: The Case of a PMO Dedicated to a Major Organizational Transformation. Project Management Journal, 42(6), 60-77. http://dx.doi.org/10.1002/pmj.20269

Aubry, M., \& Hobbs, B. (2011). A Fresh Look at the Contribution of Project Management to Organizational Performance. Project Management Journal, 42(1), 3-16. http://dx.doi.org/10.1002/pmj.20213

Aubry, M., Hobbs, B., Muller, R., \& Blomquist, T. (2010a). Identifying Forces Driving PMO Changes. Project Management Journal, 41(4), 30-45. http://dx.doi.org/10.1002/pmj.20191

Aubry, M., Muller, R., \& Glueckler, J. (2011). Exploring PMOs through Community of Practice Theory. Project Management Journal, 42(5), 42-56. http://dx.doi.org/10.1002/pmj.20259

Aubry, M., Muller, R., Hobbs, B., \& Blomquist, T. (2010b). Project Management Offices in Transition. International Journal of Project Management, 28(8), 766-778. http://dx.doi.org/10.1016/j.ijproman.2010.05.006

Ben-Zvi, T., \& Lechler, T. G. (2011). Resource Allocation in Multi-Project Environments: Planning vs. Execution strategies, Portland, OR.

Beringer, C., Jonas, D., \& Gemunden, H. G. (2012). Establishing Project Portfolio Management: An Exploratory Analysis of the Influence of Internal Stakeholders' Interactions. Project Management Journal, 43(6), 16-32. http://dx.doi.org/10.1002/pmj.21307

Blunden, C. (2010). Clean Delivery: An Experience Report of Collaborative Lean Software Delivery. In P. O. N. Abrahamsson (Ed.), Lean Enterprise Software and Systems, 65, 118-123. http://dx.doi.org/10.1007/978-3-642-16416$3 \_18$

Bratnicki, M. (2005). Organizational Entrepreneurship: Theoretical Background, some Empirical Tests, and Directions for Future Research. Human Factors and Ergonomics in Manufacturing, 15(1), 15-33. http://dx.doi.org/ 10.1002/hfm.20016

Bucur, C. M., \& Onete, B. (2008). Project Office - A Necessity In A Competitive Company. Amfiteatru Economic, $62-68$.

Cano, J. L., Lidon, I., \& Rebollar, R. (2008). Learning Project Management through Working for Real Clients. International Journal of Engineering Education, 24(6), 1199-1209.

Curlee, W. (2008). Modern Virtual Project Management: The Effects of a Centralized and Decentralized Project Management Office. Project Management Journal, 39, S83-S96. http://dx.doi.org/10.1002/pmj.20062

Czuchry, A. J. (2003). Managing the Project Management Process. Industrial Management \& Data Systems, 103(1-2), 3946. http://dx.doi.org/10.1108/02635570310456887

Dai, C. X., \& Wells, W. G., (2004). An Exploration of Project Management Office Features and their Relationship to Project Performance. International Journal of Project Management, 22, 523-532 http://dx.doi.org/ 10.1016/j.ijproman.2004.04.001

Desouza, K. C., Evaristo, J.R. (2006). Project Management Offices: A case of Knowledge Based Archetypes. International Journal of Information Management, 26, 414-423. http://dx.doi.org/10.1016/j.ijinfomgt.2006.07.002

Dey, P. K., Kinch, J., \& Ogunlana, S. O. (2007). Managing Risk in Software Development Projects: a Case Study. Industrial Management \& Data Systems, 107(1-2), 284-303. http://dx.doi.org/10.1108/02635570710723859

Engle, P. (2005). The Project Management Office. Industrial Engineer, 37(1), 20-20.

Faisal, M. N., Banwet, D. K., \& Shankar, R. (2007). Supply Chain Risk Management in SMEs: Analysing the Barriers. International Journal of Management and Enterprise Development, 4(5), 588-607. http://dx.doi.org/ 10.1504/IJMED.2007.013460

Gasik, S. (2011). A Model of Project Knowledge Management. Project Management Journal, 42(3), 23-44. http://dx.doi.org/10.1002/pmj.20239 
Georgy, M. E., Chang, L. M., \& Zhang, L. (2005). Utility-Function Model for Engineering Performance Assessment. Journal of Construction Engineering and Management-Asce, 131(5), 558-568. http://dx.doi.org/10.1061/ (ASCE)0733-9364(2005)131:5(558)

Gulledge, T. (2006). What is Integration?, Industrial Management \& Data Systems, 106(1-2), 5-20. http://dx.doi.org/10.1108/02635570610640979

Hill, G. M. (2004). Evolving the Project Management Office, a Competency Continuum. Information Systems Management, 21(4), 45-51. http://dx.doi.org/10.1201/1078/44705.21.4.20040901/84187.6

Hatfield, M. (2008). Things Your PMO Is Doing Wrong, Newtown Square. PA. Project Management Institute.

Henard, D. H., \& Szymanski, D. M. (2001). Why Some New Products are Morel, Successful than Others. Journal of Marketing Research, 38(3), 362-375. http://dx.doi.org/10.1509/jmkr.38.3.362.18861

Hoang, H. \& Rothaermel, F. T. (2005). The Effect of General and Partner-Specific Alliance Experience on Joint R\&D Project Performance. The Academy of Management Journal, 48(2), 332-345. http://dx.doi.org/10.5465/ AMJ.2005.16928417

Hobbs, B., \& Aubry, M. (2006a). Identifying the Structure that Underlies the Extreme Variety Found Among PMOs, Proceedings of PMI Research Conference 2006, Newtown Square, PA: Project Management Institute.

Hobbs, B., Aubry, M., \& Thuillier, D. (2008). "The Project Management Office as an Organizational Innovation. International Journal of Project Management, 26, 547-555. http://dx.doi.org/10.1016/j.ijproman.2008.05.008

Hobbs, B., \& Aubry, M. (2007). A Multi-Phase Research Program Investigating Project Management Offices (PMOs): the results of phase 1. Project Management Journal, 38(1).

Hobbs, B., \& Aubry, M. (2006b). Describing and Analysing Project Management Offices. Proceedings of 20th IPMA World Congress on Project Management, Vol 1/2, 588-593.

Hobbs, B., \& Aubry, M. (2008). An Empirically Grounded Search for a Typology of Project Management Offices. Project Management Journal, 39(2), S69-S82. http://dx.doi.org/10.1002/pmj.20061

Huang, S. M., Chang, I. C., Li, S. H., \& Lin, M. T. (2004). Assessing Risk in ERP Projects: Identify and Prioritize the Factors. Industrial Management \& Data Systems, 104(8-9), 681-688. http://dx.doi.org/10.1108/02635570410561672

Hurt, M., \& Thomas, J. L. (2009). Building Value Through Sustainable Project Management Offices. Project Management Journal, 40(1), 55-72. http://dx.doi.org/10.1002/pmj.20095

International Project Management Association. (2006). ICB - NCB IPMA competence baseline, version 3.0, Nijkerk, Author. 212.

Interthink Consulting, (2002). State of the PMO 2002, available from internet: http://www.interthink.ca/research/home. html (accessed on November 2011).

Isola, M., Polikaitis, A., \& Laureto, R. A. (2006). Implementation of a Project Management Office (PMO)-experiences from year 1. Journal of Healthcare Information Management, 20(1), 9-87.

Julian, J. (2008). How Project Management Office Leaders Facilitate Cross-Project Learning and Continuous Improvement. Project Management Journal, 39(3), 43-58. http://dx.doi.org/10.1002/pmj.20071

Kerzner, H. (2003). Strategic Planning for a project office. Project Management Journal, 34(2), 13-25.

Kropf, R., \& Scalzi, G. (2008). Great project management=IT success. Physician executive, 34(3), 38-40.

Levina, N. and Su, N. (2008). Global Multisourcing Strategy: The Emergence of a Supplier Portfolio in Services Offshoring. Decision Sciences, 39, 541-570. http://dx.doi.org/10.1111/j.1540-5915.2008.00202.x

Lewis, M. W., Welsh, M. A., Dehler, G. E., \& Green, S. G. (2002). Product Development Tensions: Exploring Contrasting Styles of Project Management. Academy of Management Journal, 45(3), 546-564. http://dx.doi.org/ 10.2307/3069380

Liang, T.-P., Liu, C.-C., Lin, T. M., \& Lin, B. (2007). Effect of team Diversity on Software Project Performance. Industrial Management \& Data Systems, 107(5-6), 636-653. http://dx.doi.org/10.1108/02635570710750408

Liebowitz, J. (2003). A Knowledge Management Strategy for the Jason Organization: A case study, Journal of Computer Information Systems, 44(2), 1-5.

Liu, L., \& Yetton, P. (2007). The Contingent Effects on Project Performance of Conducting Project Reviews and Deploying Project Management Offices. IEEE Transactions on Engineering Management, 54, 789-799. http://dx.doi.org/10.1109/TEM.2007.906852

Lindner, F., \& Wald, A. (2011). Success Factors of Knowledge Management in Temporary Organizations. International Journal of Project Management, 29(7), 877-888. http://dx.doi.org/10.1016/j.ijproman.2010.09.003

Lopez-Paredes, A., Pajares-Gutierrez, J., \& Manuel Galan-Ordax, J. (2010). Managing Firm as Project and Program Portfolio, Dyna, 85(1), 39-46. 
Maguire, S., Ojiako, U., \& Said, A. (2010). ERP Implementation in Omantel: a Case Study. Industrial Management \& Data Systems, 110(1-2), 78-92. http://dx.doi.org/10.1108/02635571011008416

Martin, N. L., Pearson, J. M., \& Furumo, K. (2007). IS Project Management: Size, Practices and the Project Management Office. Journal of Computer Information Systems, 47(4), 52-60.

Meredith, J. R., \& Mantel, S. J. (2011). Project Management: A Managerial Approach. John Wiley \& Sons, 289.

Mulenburg, G. M. (2005). The Complete Project Management Office Handbook. Journal of Product Innovation Management, 22(3), 298-300. http://dx.doi.org/10.1111/j.0737-6782.2005.125_4.x

Niu, N., Jin, M. Z., \& Cheng, J. R. C. (2011). A Case Study of Exploiting Enterprise Resource Planning Requirements. Enterprise Information Systems, 5(2), 183-206. http://dx.doi.org/10.1080/17517575.2010.519052

Okrent, M. D., \& Vokurka, R. (2004). Process Mapping in Successful ERP Implementations. Industrial Management \& Data Systems, 104(8-9), 637-643. http://dx.doi.org/10.1108/02635570410561618

Paliszkiewicz, J. (2007). Knowledge Management: An Integrative View and Empirical Examination. Cybernetics and Systems, 38(8), 825-836. http://dx.doi.org/10.1080/01969720701601148

Pemsel, S., \& Wiewiora, A. (2013). Project Management Office a Knowledge Broker in Project-Based Organisations. International Journal of Project Management, 31(1), 31-42. http://dx.doi.org/10.1016/j.ijproman.2012.03.004

Pellegrinelli, S. (2011). What's in a Name: Project or Programme?. International Journal of Project Management, 29(2), 232-240. http://dx.doi.org/10.1016/j.ijproman.2010.02.009

Piraquive, F. N. D., Garcia, V. H. M., \& Aguilar, L. (2013). Technological Tools Virtual Collaborative to Support Knowledge Management in Project Management. 7th International Conference on Knowledge Management in Organizations: Service and Cloud Computing, 172, 163-174. http://dx.doi.org/10.1007/978-3-642-30867-3_15

Project Management Institute (2013). A Guide to the Project Management Body of Knowledge (PMBOK ${ }^{\circledR}$ Guide)-Fifth Edition, Newtown Square, PA: Author.

Rad, P. F., \& Levin, G. (2002). The advanced Project Management Office. a Comprehensive Look at Function and Implementation. CRC Press LLC, Boca Raton, USA, 224.

Ritter, T., \& Gemunden, H. G. (2004). The Impact of a Company's Business Strategy on its Technological Competence, Network Competence and Innovation Success. Journal of Business Research, 57(5), 548-556. http://dx.doi.org/10.1016/S0148-2963(02)00320-X

Romanowska, M. (2009). Effectiveness of Reorganization of an Enterprise Operating in a Globalized Sector. Transformations in Business and Economics, 8(3 SUPPL. B), 83-93.

Singh, R., Keil, M., \& Kasi, V. (2009). Identifying and Overcoming the Challenges of Implementing a Project Management office. European Journal of Information Systems, 18(5), 409-427. http://dx.doi.org/ 10.1057/ejis.2009.29

Soja, P., \& Paliwoda-Pekosz, G. (2009). What are Real Problems in Enterprise System Adoption?. Industrial Management \& Data Systems, 109(5-6), 610-627. http://dx.doi.org/10.1108/02635570910957614

Spalek, S. (2012). The Role of Project Management Office in the Multi-Project Environment. International Journal of Management and Enterprise Development, 12(2), 172-188. http://dx.doi.org/10.1504/IJMED.2012.047891

Spalek, S. (2010). The Project Management Office Concept Supporting the Decision Making Process Within an Organisation. Scientific Monograph Collection Knowledge Base for Management - Theory and Practice, EDIS University Publishing House.

Stabryla, A. (ed.), \& Wozniak K. (ed.), (2012). Determinants of Capacity in Organizational Development, [In Polish], Cracow: Mfiles.pl.

Standing, C., Guilfoyle, A., Lin, C., \& Love, P. E. D. (2006). The Attribution of Success and Failure in IT Projects. Industrial Management \& Data Systems, 106(8), 1148-1165. http://dx.doi.org/10.1108/02635570610710809

Stanleigh, M. (2006). From Crisis to Control: New Standards for Project Management. Ivey Business Journal Online, $70(4), 2-4$.

Trocki, M. (ed.), Bukłaha, E., Grucza, B., Juchniewicz, M., Metelski, W., \& Wyrozębski, P. (2012). Modern Project Management, [In Polish], Warsaw: PWE.

Umble, E. J., Haft, R. R., \& Umble, M. M. (2003). Enterprise Resource Planning: Implementation Procedures and Critical Success Factors. European Journal of Operational Research, 146(2), 241-257. http://dx.doi.org/10.1016/S03772217(02)00547-7

Zavadskas, E. K., Vainiunas, P., Turskis, Z., \& Tamosaitiene, J. (2012). Multiple Criteria Decision Support System for Assessment of Projects Managers in Construction. International Journal of Information Technology \& Decision Making, 11(2), 501-520. http://dx.doi.org/10.1142/S0219622012400135 